\title{
Bioassessment of Water Quality of Mountainous Streams under Different Land Uses in Solan District of Himachal Pradesh, India
}

\author{
Aakriti Chauhan $^{* 1}$, S. C. Verma ${ }^{2}$ and Meena Thakur ${ }^{3}$ \\ ${ }^{1}$ Dept. of Environmental Science, ${ }^{2}$ Dept. of Seed Science and Technology, ${ }^{3}$ Dept. of Environmental Science, Dr Y S Parmar \\ University of Horticulture and Forestry, Nauni, Solan, Himachal Pradesh, (173 230), India
}

\section{Article History}

Manuscript No. AR957

Received in $8^{\text {th }}$ October, 2014

Received in revised form $15^{\text {th }}$ December, 2014

Accepted in final form $29^{\text {th }}$ January, 2015

\section{Correspondence to}

"E-mail: aakriti.chauhan89@gmail.com

\section{Keywords}

Water quality, land uses, seasons, aquatic insects

\begin{abstract}
Investigations were carried out in the Environmental Biology Laboratory of Department of Environmental Science, Dr Y S Parmar University of Horticulture and Forestry, Nauni, Solan, Himachal Pradesh, India during 2011-2012. Aquatic insects fauna were sampled from mountaineous streams of Kandaghat block situated in Solan district under different land uses (agriculture, forest and urban) seasons (rainy, winter and summer). The sampled aquatic insects were identified upto family level by using aquatic insect identification keys with help of stereoscopic binocular microscope. A total of 80 individuals $\mathrm{m}^{-2}$ and 59 individuals $\mathrm{m}^{-2}$ of aquatic insects were recorded under agriculture and urban land uses, respectively. Among all the land uses, forest land use recorded highest aquatic insects $\left(107 \mathrm{~m}^{-2}\right)$. Maximum aquatic insects (123 $\mathrm{m}^{-2}$ ) was during summer season with simpson's biodiversity index of 0.01 , whereas agriculture land use (0.11) was highest under different land uses. Maximum diversity of insects indicated less disturbance of the streams. EPT (Ephemeroptera, Plecoptera and Coleoptera) index for agriculture, urban and forest land uses was 3.46, 3.70 and 3.56, respectively. Percentage of individuals of Trichoptera in water bodies under agriculture, Urban and Forest land use were 12.60, 10.98 and $10.16 \%$, respectively. Hemiptera were maximum $(7.31 \%)$ under forest land use and minimum in Urban land use $(2.03 \%)$, whereas order Odonata were maximum under Forest land use $(9.31 \%)$ followed by urban $(5.69 \%)$ and agriculture land use $(4.47 \%)$. This indicated that aquatic insect fauna showed variation in distribution and abundance as well as biotic indices in mountainous streams under different land uses thereby reflecting good water quality.
\end{abstract}

\section{Introduction}

Biological assessments of human and environmental impacts on water quality and aquatic organisms have been used since the early 1900s (Wallace et al., 1996). The biological approach for assessing streams and rivers is the use of benthic macroinvertebrates, especially aquatic insects, as indicators of pollution (Dudgeon, 1999). There is a high probability that human-induced change will also result in a change in the composition of the benthic community. The use of benthic macroinvertebrates is widespread and constitutes the basis for most aquatic biomonitoring programs currently in use (Metcalfe, 1989). As the aquatic insects are the major species of macroinvertebrates, their specific and predictable responses to changes in landscape and physico-chemical factors are relatively easy to measure and interpret. A study on the community structure of aquatic insects is useful in biological integrity analysis (Oberdorff et al., 2001). The change in the community structure of the aquatic insects is a widely used tool for monitoring water quality and stream ecology. Benthic macro invertebrates are an important component of aquatic communities because of their large distribution, being found in the sediment, in accumulated leaves, associated with macrophytes between the rocks and therefore they interact with the environmental conditions (Wurdig et al., 2007). These communities showed different distributions in the space and time that vary in accordance with the morphology and physico-chemical conditions of water (Silveira et al., 2006). Therefore their presence is an important indicator of watershed health (Lee and Rudd, 2003). The use of aquatic insects for assessing water quality provides information to environmental managers and decisions makers to take accurate and justifiable 
actions with regards to the state and quality of water bodies (Arimoro and Ikomi, 2008). Standard physico-chemical water quality measures provide information on water quality at a particular spatial unit during the time of sampling. It cannot provide historical information on water quality. On the other hand, by knowing the ecology of aquatic insect community, biomonitoring tools provide some historic insight into the water quality (Subramanian and Sivaramakrishnan, 2007).

\section{Materials and Methods}

2.1. Collection, preservation and clearing of aquatic insect specimens

The aquatic insects were collected as per method of Subramanian and Sivarama Krishnan (2007). The aquatic insects from water body were collected by using aquatic insect net (Mesh size 40-80 $\mathrm{cm}^{-2}$ ). All fresh specimens collected from surface water under different land uses were stored in $70 \%$ ethanol for sorting and identification in the laboratory. After that insect specimens were transferred to $35 \%$ lactic acid in cavity blocks which were covered and kept at $35-40{ }^{\circ} \mathrm{C}$ in oven for clearing of sample for a period of one week. The samples were mounted on slide in a Hoyer's media and covered with cover slips. The Hoyer's medium was prepared as per method of (Baker and Wharton, 1952). The insects were identified to the family level by using a taxonomical key of Brues et al. (1954) and Dudgeon (2000). The numbers of individuals in each family were counted.

\section{Results and Discussion}

It is evident from Table 1 that a total 246 individuals of aquatic insects under 10 families and 6 orders were recorded in mountainous streams. The maximum (107 individuals $\mathrm{m}^{-2}$ ) of aquatic insects were recorded under forest land use and minimum under urban land use (59 individuals $\mathrm{m}^{-2}$ ). Maximum number of individuals was recorded during summer season (123 individuals $\mathrm{m}^{-2}$ ) and minimum during rainy season (55 individuals $\mathrm{m}^{-2}$ ) whereas during winter season 68 individuals $\mathrm{m}^{-2}$ were recorded. In the present findings variable number of aquatic insects were recorded under different land uses during different seasons under Ephemeroptera, Plecoptera, Trichoptera, Odonata, Hemiptera and Coleoptera orders. These findings confirms the findings of Sharma et al. (2006) who reported Ephemeroptera, Trichoptera, Plecoptera, Coleoptera and Odonata in Behta river of Ponta Sahib in Himachal Pradesh.

It is well established fact that many insects' species have life cycle that are seasonal, and that results in fluctuations in the number of certain group of macro invertebrates occurring in samples taken from the stream bed at different times of year (Hynes, 1972). Under agriculture land use system Hydropsychidae ( 20 individuals $\mathrm{m}^{-2}$ ) of Trichoptera order were recorded during summer season followed by Ephemerellidae ( 8 individuals $\mathrm{m}^{-2}$ ) of Ephemeroptera. Maximum abundance of aquatic insects under agriculture land use during summer season may be due to availability of food, consistent flow rate of water and temperature of the water body. Under agriculture land use system during rainy season Hygrobiidae of Coleopteran ( 0 individual $\mathrm{m}^{-2}$ ) and Libellulidae of Odonata ( 1 individual $\mathrm{m}^{-2}$ ) and Leuctridae of Plecoptera ( 2 individuals $\mathrm{m}^{-2}$ ) were least in count. Minimum number of aquatic insects under agriculture land use during rainy season may be due to fluctuations in flow of water body which may deplete the fauna directly or indirectly by affecting the food base and by reducing the habitat diversity. In present findings, the temperature of water body was in the range of $19.75^{\circ} \mathrm{C}$ to $24.75^{\circ} \mathrm{C}$. The present findings are in confirmation with the findings of Mishra and Nautiyal (2011) who reported Hydropsychidae of Trichoptera, Baetidae of Ephemeroptera and Gomphidae of Odonata under agriculture land use at the temperature range between 16.5 to $21.50^{\circ} \mathrm{C}$.

Under urban land use, 59 individuals $\mathrm{m}^{-2}$ were recorded amongst them Hydropsychidae of Trichoptera were the dominant during all the three seasons and maximum (15 individuals $\mathrm{m}^{-2}$ ) were recorded during summer season. During rainy season, under urban land use the fauna was less diverse, this may be due to high flow rate of water body due to rainfall, addition of domestic waste and accumulation of sedimentary detritus (Ward, 1974) where as during summer season presence of Hydropsychidae indicated that water environment was suited for their survival because of availability of food, minimum flow rate of water and presence of oxygen in water body.

Maximum numbers of aquatic insects were recorded under forest land use system (107 individuals $\mathrm{m}^{-2}$ ). Hydropsychidae of Trichoptera was the dominant family during summer season, Batidae during winter season and Girridae during rainy season and Plecoptera was nil in all the three seasons. Sprules (1947) showed that number and diversity of Plecoptera decreases with increasing average summer temperature, the number and diversity of Ephemeroptera and Trichoptera increases thereby avoiding strong seasonal differences of EPT index scores. During summer season under forest land use maximum abundance of aquatic insects may be due to presence of food mainly algae, constant flow of water body and availability of oxygen for the survival of insects. These findings are in confirmation with the findings of Bahuguna et al. (2004) who reported Ephemeroptera, Trichoptera, Coleoptera in the Veerbhadra barrage during the month of January when the temperature of water body was in the range of 20 to $22^{\circ} \mathrm{C}$ under 
forest land use system and in the present investigations on an average temperature of water body at the time of sampling ranged between $19.75^{\circ} \mathrm{C}$ to $24.75^{\circ} \mathrm{C}$.

Data contained in Table 2 revealed that the overall EPT biotic index was 3.55 and EPT index was $>27$ (Table 3) which indicated "Excellent water quality". The higher EPT index under forest land use may be due to clean environment and lowest EPT index (18) during rainy season indicated good to fair water quality which may be due to high loads of organic and inorganic suspended materials.
On over all basis Family biotic index (FBI) of aquatic insects of surface water was 3.07. Family biotic index under agriculture land use (2.83) urban land use (3.83) and forest land use (2.12) during different seasons also indicated good to excellent water quality (Table 4). The present findings are in confirmation with findings of Armitage et al. (1983) who reported that the biological indices provided better information about the environmental conditions under which they lived than a consideration of the individual taxa alone.

Simpson's biodiversity index for rainy, winter and summer

\begin{tabular}{|c|c|c|c|c|c|c|}
\hline \multirow[t]{2}{*}{ Land use } & \multirow[t]{2}{*}{ Order } & \multirow[t]{2}{*}{ Family } & \multicolumn{3}{|c|}{ Season } & \multirow[t]{2}{*}{ Total } \\
\hline & & & Rainy & Winter & Summer & \\
\hline \multirow{11}{*}{ Agriculture } & Ephemeroptera & Batidae & 3 & 6 & 2 & 11 \\
\hline & & Haptagenidae & 2 & 0 & 0 & 2 \\
\hline & & Ephemerellidae & 0 & 0 & 8 & 8 \\
\hline & & Ephemeridae & 0 & 0 & 6 & 6 \\
\hline & Plecoptera & Leuctridae & 2 & 0 & 0 & 2 \\
\hline & Trichoptera & Hydropsychidae & 4 & 7 & 20 & 31 \\
\hline & Odonata & Gomphidae & 3 & 4 & 3 & 10 \\
\hline & & Libellulidae & 1 & 0 & 0 & 1 \\
\hline & Hemiptera & Girridae & 6 & 3 & 0 & 9 \\
\hline & Coleoptera & Hygrobiidae & 0 & 0 & 0 & 0 \\
\hline & & Total & & & & 80 \\
\hline \multirow{11}{*}{$\begin{array}{l}\text { Urban or } \\
\text { suburban }\end{array}$} & Ephemeroptera & Batidae & 0 & 0 & 1 & 1 \\
\hline & & Haptagenidae & 0 & 0 & 1 & 1 \\
\hline & & Ephemerellidae & 0 & 0 & 4 & 4 \\
\hline & & Ephemeridae & 0 & 0 & 7 & 7 \\
\hline & Plecoptera & Leuctridae & 0 & 0 & 0 & 0 \\
\hline & Trichoptera & Hydropsychidae & 2 & 10 & 15 & 27 \\
\hline & Odonata & Gomphidae & 1 & 3 & 2 & 6 \\
\hline & & Libellulidae & 1 & 4 & 3 & 8 \\
\hline & Hemiptera & Girridae & 3 & 2 & 0 & 5 \\
\hline & Coleoptera & Hygrobiidae & 0 & 0 & 0 & 0 \\
\hline & & Total & & & & 59 \\
\hline \multirow[t]{11}{*}{ Forest } & Ephemeroptera & Batidae & 4 & 8 & 3 & 15 \\
\hline & & Haptagenidae & 0 & 2 & 3 & 5 \\
\hline & & Ephemerellidae & 0 & 0 & 9 & 9 \\
\hline & & Ephemeridae & 0 & 0 & 7 & 7 \\
\hline & Plecoptera & Leuctridae & 0 & 0 & 0 & 0 \\
\hline & Trichoptera & Hydropsychidae & 1 & 4 & 20 & 25 \\
\hline & Odonata & Gomphidae & 4 & 6 & 5 & 15 \\
\hline & & Libellulidae & 1 & 3 & 4 & 8 \\
\hline & Hemiptera & Girridae & 12 & 6 & 0 & 18 \\
\hline & Coleoptera & Hygrobiidae & 5 & 0 & 0 & 5 \\
\hline & & Total & & & & 107 \\
\hline Total & 6 & 10 & 55 & 68 & 123 & 246 \\
\hline
\end{tabular}


season was $0.01,0.02$ and 0.0 , respectively (Table 5) which indicated maximum diversity of aquatic insects during summer season. Maximum diversity of insects indicated less disturbance of the streams. . The present findings are supported by the findings of Turkmen and Kazanci (2010) who reported that the values of Simpson diversity index ranged between 0.66-0.94 at Yedigoller National Park. As shown in Figure 1, 2 and 3, the percentage of individuals of order Trichoptera of family Hydropsychidae in water bodies under agriculture, Urban and Forest land use were 39, 46 and 23\%, respectively. Family Girridae of order Hemiptera were maximum (17\%) under forest land use (Figure 3) and minimum in urban land use (8\%) shown in Figure 2. Batidae family of order Ephemeroptera was $14 \%$ under agriculture and forest land use (Figure 2 and 3 ).

In Coleoptera family, Hygrobiidae was present only in forest land use which was 5\% represented in Figure 3. Gomphidae family of Odonata order was 13,10 and 14\% in agriculture, urban or suburban and forest land uses represented in Figure 1,2 and 3.

The distribution of the macroinvertebrate communities depends on multiple environmental factors acting at different spatialtemporal scales (Boyero, 2003). These findings corroborate the findings of Diamond et al. (2002). Who have found that human land use activities affects native aquatic insects in the clinch and Powell river watershed, USA. This indicated that aquatic

Table 2: EPT biotic index under different land uses during different seasons

\begin{tabular}{lcccccc}
\hline \multicolumn{3}{c}{ Land use } & \multicolumn{3}{c}{ Seasons } & Overall \\
\cline { 1 - 6 } Agriculture & Urban & Forest & Rainy & Winter & Summer & \\
\hline 3.46 & 3.70 & 3.56 & 3.52 & 4.00 & 3.43 & 3.55 \\
\hline
\end{tabular}

Table 3: EPT index under different land use during different seasons

\begin{tabular}{lccccc}
\hline \multicolumn{3}{c}{ Land use } & \multicolumn{3}{c}{ Seasons } \\
\hline Agriculture & Urban & Forest & Rainy & Winter & Summer \\
\hline 60 & 40 & 61 & 18 & 37 & 106 \\
\hline
\end{tabular}

Table 4: Family biotic index for different seasons and land uses

\begin{tabular}{lcccccc}
\hline \multicolumn{3}{c}{ Land use } & \multicolumn{3}{c}{ Seasons } & \multirow{2}{*}{ Overall } \\
\cline { 1 - 6 } Agriculture & Urban & Forest & Rainy & Winter & Summer & \\
\hline 2.83 & 3.83 & 2.12 & 1.75 & 3.25 & 3.54 & 3.07 \\
\hline
\end{tabular}

Table 5: Simpson's biodiversity index during different seasons under different land uses

\begin{tabular}{lccccc}
\hline \multicolumn{3}{c}{ Land use } & \multicolumn{3}{c}{ Seasons } \\
\hline Agriculture & Urban & Forest & Rainy & Winter & Summer \\
\hline 0.11 & 0.05 & 0 & 0.01 & 0.02 & 0 \\
\hline
\end{tabular}

insect fauna showed variation in distribution and abundance as well as biotic indices in mountainous streams under different land uses thereby reflecting good water quality.

Batidae Haptageenidae $\square$ Ephemertellidae

Ephemeridae Leuctridae Hydropsychidae

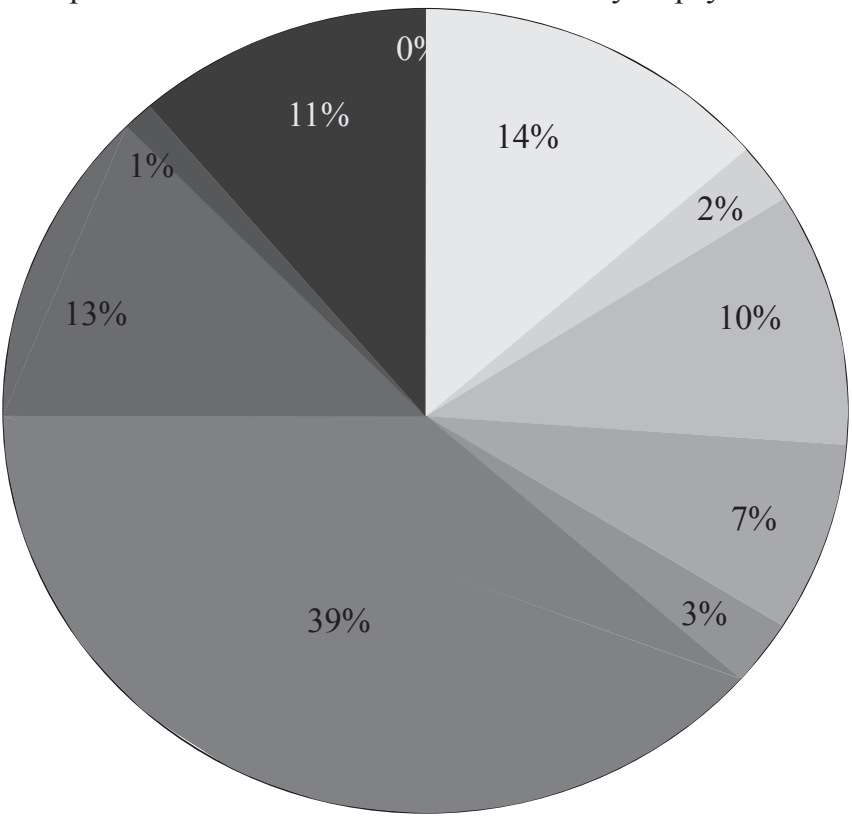

Gomphidae Libellulidae Girridae Hygrobiidae

Figure1. Percent composition of different families of aquatic insects under agriculture land use

Batidae Haptageenidae $\square$ Ephemertellidae

Ephemeridae Leuctridae Hydropsychidae

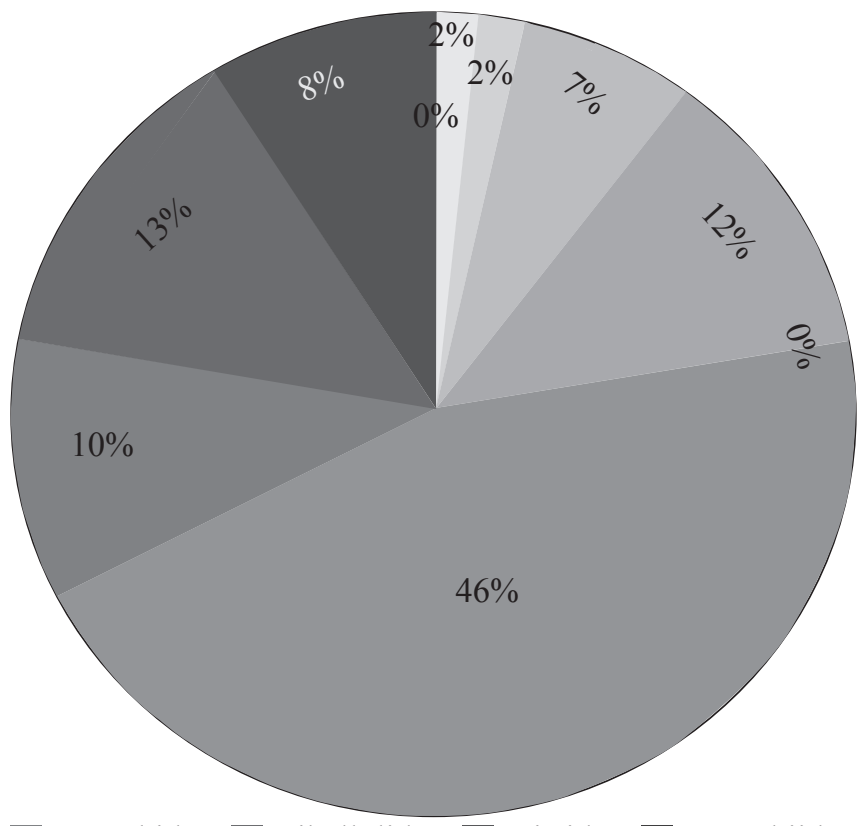

Gomphidae Libellulidae Girridae $\square$ Hygrobiidae

Figure 2: Percent composition of different families of aquatic insects under urban/suburban land use 
Batidae $\square$ Haptageenidae $\square$ Ephemertellidae

Ephemeridae Leuctridae Hydropsychidae

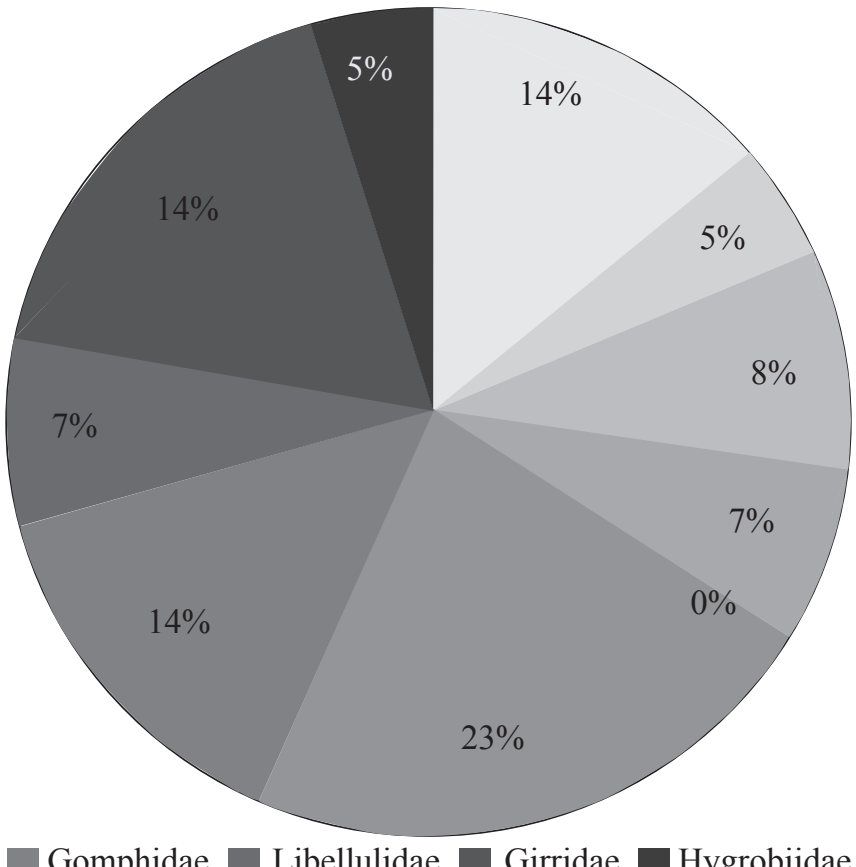

Gomphidae $\square$ Libellulidae Girridae $\square$ Hygrobiidae

Figure 3: Percent composition of different families of aquatic insects under forest land use

\section{Conclusion}

Bioassessment of mountainous streams during three seasons under different land uses shows good to excellent water quality, significant variation is observed in aquatic insects' population due to seasonal changes and different land use practices.

\section{Acknowledgement}

Authors are thankful to Professor and Head of Department of Environmental Science for providing all the facilities required for conducting this research work.

\section{References}

Arimoro, F.O., Ikomi, R.B., 2008. Ecological integrity of upper Warri river, Niger Delta using aquatic insects as bioindicators. Ecological Indicator 395, 1-7.

Armitage, P.D., Moss, D., Wright, J.F., Furse, M.T., 1983. The performance of a new biological water quality score system based on macro invertebrates over a wide range of unpolluted running-water sites. Water Research 17, 333-347.

Bahuguna, B.K., Nautiyal, R., Nautyal, P., Singh, H.R., 2004. Stream regulation: Variation in the density, composition and diversity of benthic macro invertebrates occurring in the up and down stream section of impounded zone of the river Ganga in the Foothills. Tropical Ecology
45(2), 251-261.

Baker, E.W., Wharton, G.W., 1952. An introduction to Acarology. Macmillan Company, New York, 465.

Boyero, L., 2003. Multiscale patterns of spatial variation in stream macro invertebrate communities. Ecology Research 18, 365-379.

Brues, C.T., Melander, A.L., Carpenter, F.M., 1954. Classification of insects. Cambridge Mass, USA, 826.

Diamond, J.M., Bressler, D.W., Serveiss, V.B., 2002. Assessing relationships between human land uses and the decline of native mussels, fish, and macro invertebrates in the Clinch and Powell river watershed, USA. Environmental Toxicology and Chemistry 21(6), 1147-1155.

Dudgeon, D., 1999. Tropical Asian Streams: Zoobenthos. Ecology and Conservation, Hong Kong University Press.

Hynes, H.B.N., 1972. The ecology of running waters. University of Toronto press, Toronto, 555.

Lee, N., Rudd, H., 2003. Conserving biodiversity in greater Vancouver: Indicator species and habitat quality. Dougals College, Institute of urban ecology $2^{\text {nd }}$ edition.

Metcalfe, J.L., 1989. Biological water quality assessment of running waters based on macroinvertebrate communities: history and present status in Europe. Environmental Pollution 60, 101-139.

Mishra, A.S., Nautiyal, P., 2011. Factors governing longitudinal variation in benthic macroinvertebrate fauna of a small Vindhyan river in central highlands ecoregion (Central India). Tropical Ecology 52(1), 103-112.

Oberdorff, T., Pont, D., Hugheny, B., Chessel, D., 2001. A probabilistic model haracterizing riverine fish communities of French rivers: a framework for environmental assessment. Freshwater Biology 46, 399-415.

Sharma, M.P., Sharma, S., Goel, V., Sharma, P., Kumar, A., 2006. Water quality assessment of Bheta river using benthic macro invertebrates. Life Science Journal 3(4), 68-74.

Silveira, M.P., Buss, D.F., Nessimian, J.L., Baptista, D.F., 2006. Spatial and temporal distribution of benthic macro invertebrates in South Eastern Brazilian river. Brazilian Journal of Biology 66(2), 623-632.

Sprules, V.M., 1947. An ecological investigation of stream insects in Algonquin Park, Ontario. University Toronto Studies, Biology Series 56, 1-81.

Subramanian, K.A., Sivaramakrishnan, K.G., 2007. Aquatic insects for biomonitoring fresh Ecosystem-A methodology manual, Ashoka Trust for Ecology and Environment, Banglore: India, 31.

Turkmen, G., Kazanci, N., 2010. Applications of various diversity indices to benthic macro invertebrate 
assemblages in streams of a natural park in Turkey. Balwois 25, 1-10.

Wallace, J.B., Grubaugh, J.W., Whiles, M.R., 1996. Biotic indices and stream ecosystem processes: Results from an experimental study. Ecological Applications 6(1), 140-151.

Ward, J.V., 1974. A temperature stressed stream ecosystem below a hypolimnial release mountain reservoir. Archiv Fur Hydrobiologie 74, 247-275.

Wurdig, N.L., Cenzano, C.S.S., Motta, D.M., 2007. Macro invertebrate communities structure in different environments of the Taim hydrological system in the state of Rio Grande do Sul, Brazil. Acta Limnology Brasil 19(4), 57-68. 